UDC [620.1:678-1]:534.083

M.O. Golofeyeva, PhD, Assoc.Prof.,

V.M. Tonkonogy, DEng, Prof.,

Yu.M. Golofeyev

Odessa National Polytechnic University, 1 Shevchenko Ave., 65044 Odessa, Ukraine; e-mail: mary_sya@ukr.net

\title{
THE UNCERTAINTIES CALCULATION OF ACOUSTIC METHOD FOR MEASUREMENT OF DISSIPATIVE PROPERTIES OF HETEROGENEOUS NON-METALLIC MATERIALS
}

М.О. Голофєєва, В.М. Тонконогий, Ю.М. Голофєєв. Розрахунок невизначеностей акустичного методу вимірювання дисипативних властивостей неметалевих гетерогенних матеріалів. Ефективне використання неметалевих гетерогенних матеріалів та конструкцій з них потребує вимірювання достовірних значень характеристик дисипації, а також закономірності їх змінення в процесі навантаження. Мета: Метою дослідження є складання бюджету невизначеностей вимірювання дисипативних властивостей композиційних матеріалів. Матеріали і методи: Розглянуто метод дослідження характеристик розсіювання енергії коливань, заснований на зв'язку декременту затухання коливань та швидкості розповсюдження акустичних хвиль в неметалевому гетерогенному матеріалі. Запропонований метод дослідження дає можливість виявити залежність демпфування від амплітуди та частоти коливань, напружено-деформованого стану матеріалу. Результати: Проведено дослідження точності методу вимірювання при визначені декременту затухання коливань в синтеграні. Підхід, який використано для оцінювання якості вимірювань, включає єдині в міжнародній практиці правила вираження невизначеностей та їх підсумовування. Складено бюджет невизначеностей акустичного методу вимірювання дисипативних властивостей матеріалів. Висновки: Було встановлено, що існують дві групи причин, які призводять до помилок при вимірюваннях дисипативних властивостей матеріалів. До першої групи причин відносяться змінення параметрів тарованого удару в допустимих межах, зміщення датчиків при повторному встановленні в точку вимірювання, коливання товщини шару контактної речовини внаслідок нерівномірного притискання перетворювачів до поверхні контролю, неточність зчитування показань та ін. Друга група помилок пов'язана з похибками вимірювання щільності та коефіцієнту Пуассона матеріалу, відстані між датчиками, різниці в часі сигналів від віброакустичних датчиків.

Ключові слова: дисипативні властивості, декремент затухання, акустичний метод вимірювання, невизначеність вимірювання

M.O. Golofeyeva, V.M. Tonkonogy, Yu.M. Golofeyev. The uncertainties calculation of acoustic method for measurement of dissipative properties of heterogeneous non-metallic materials. The effective use of heterogeneous non-metallic materials and structures needs measurement of reliable values of dissipation characteristics, as well as common factors of their change during the loading process. Aim: The aim of this study is to prepare the budget for measurement uncertainty of dissipative properties of composite materials. Materials and Methods: The method used to study the vibrational energy dissipation characteristics based on coupling of vibrations damping decrement and acoustic velocity in a non-metallic heterogeneous material is reviewed. The proposed method allows finding the dependence of damping on vibrations amplitude and frequency of strain-stress state of material. Results: Research of the accuracy of measurement method during the definition of decrement attenuation of fluctuations in synthegran was performed. The international approach for evaluation of measurements quality is used. It includes the common practice international rules for uncertainty expression and their summation. These rules are used as internationally acknowledged confidence measure to the measurement results, which includes testing. The uncertainties budgeting of acoustic method for measurement of dissipative properties of materials were compiled. Conclusions: It was defined that there are two groups of reasons resulting in errors during measurement of materials dissipative properties. The first group of errors contains of parameters changing of calibrated bump in tolerance limits, displacement of sensor in repeated placement to measurement point, layer thickness variation of contact agent because of irregular hold-down of resolvers to control surface, inaccuracy in reading and etc. The second group of errors is linked with density and Poisson's ratio measurement errors, distance between sensors, time difference between signals of vibroacoustic sensors.

Keywords: dissipative properties, damping decrement, an acoustic measurement method, measurement uncertainty.

Introduction. The main advantage of heterogeneous non-metallic materials over traditional

DOI 10.15276/opu.3.47.2015.15

(c) 2015 The Authors. This is an open access article under the CC BY license (http://creativecommons.org/licenses/by/4.0/). 
consists in the increased vibrostability. The effective use of these materials and structures needs measurement of reliable values of dissipation characteristics, as well as common factors of their change during the loading process.

Various mechanisms and corresponding models for measurement of reliable values of traditional materials' dissipation characteristics are exposed by such authors as: G.S. Pysarenko, N.N. Afanasyev, A.Yu. Ishlinsky, V.L. Biderman, V.V. Matveev, V.T. Troshchenko and others. The monographs by B.L. Pelech, B.I. Salyak, V.V. Bolotin, V.V. Vasilyev, Yu.N. Novychkov, A.P. Yakovlev, A.N. Guz, V.P. Tamuzh and others have been devoted to the elaboration of research methods applied to the damping in the non-metallic heterogeneous materials.

The heterogeneous non-metallic materials are characterized by complex processes of energy dissipation due to such factors [1]:

- Internal damping with viscid matrix and hard fillers;

- Structural dissipation on the "matrix - filler" distribution boundaries.

The aforementioned experimental methods used in the study of dissipative properties of heterogeneous non-metallic materials, characterized by complex energy dissipation processes, lead to significant errors and makes impossible to determine the effect of each separately existing energy dissipation mechanisms.

The acoustic method for measurement of dissipative properties of heterogeneous non-metallic materials allows finding the dependence of damping on vibrations amplitude and frequency of strainstress state of material. Moreover, this method can be used not only for samples of the material but also for finished products. Although the method has several advantages, the problem of accuracy of the obtained results is remains relevant today.

The aim of this study is to prepare the budget for measurement uncertainty of dissipative properties of composite materials.

Materials and Methods. The method used to study the vibrational energy dissipation characteristics based on coupling of vibrations damping decrement and acoustic velocity in a nonmetallic heterogeneous material. The dependence of the vibrations damping decrement on the material's elastic modulus is described by the formula [1]:

$$
\lambda=2,076 \cdot 10^{-5} \cdot E^{2}-2,109 \cdot 10^{-3} \cdot E+0,073,
$$

where $\lambda$ - vibrations damping decrement;

$E$ - material's elastic modulus, GPa.

The propagation velocity of transverse acoustic wave over controlled environment, i.e. synthegran, can be found according to [2] as

$$
C=\sqrt{\frac{E}{2 \rho(1+v)}},
$$

where $C$ - propagation velocity of transverse acoustic wave over synthegran, $\mathrm{m} / \mathrm{s}$;

$\rho$ - synthegran density, $\mathrm{kg} / \mathrm{m}^{3}$;

$v$ - Poisson's ratio.

By substituting (2) into (1), we obtain the dependence of the vibrations damping decrement on the velocity of acoustic wave at synthegran:

$$
\lambda=8,304 \cdot 10^{-5} \rho^{2}(1+v)^{2} C^{4}-4,218 \cdot 10^{-3} \rho(1+v) C^{2}+0,073 .
$$

Figure 1 shows the scheme of the setup for measurement of the acoustic wave velocity.

A test sample attached to a console. On it, at a fixed distance $S$ (sound control base) is a set of the vibroacoustical piezoelectric sensors AVS-117 (all sensors are identical in size and weight) which receiving signals, which are proportional to the displacement. The sample is subjected to shock loading. The torque strike is implemented by the falling steel ball (diameter of $40 \mathrm{~mm}$, drop height of $200 \mathrm{~mm}$ ). The guide cylinder, which is set perpendicular to the controlled surface, provides the ball dropping to required point of surface. 
The sensors' signals are registered by the electronic diagnostic complex "Dolphin-1M", which provides switching, coordination, pre-filtering and input of measured data to a computer via an analogto-digital converter. Each channel frequency response is $280 \mathrm{kHz}$.

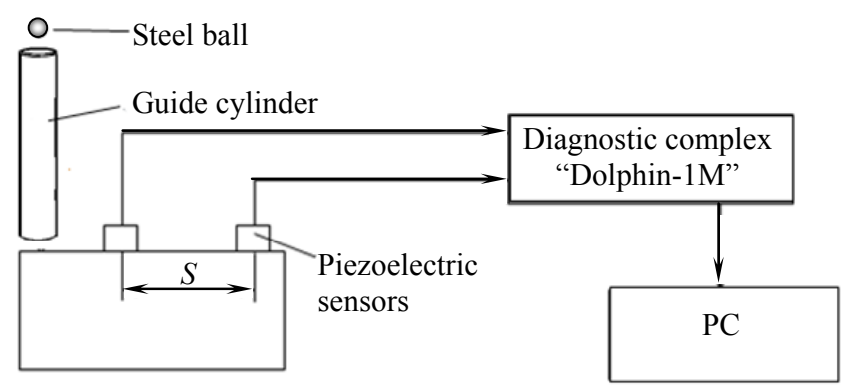

Fig. 1. Scheme of the setup for measurement of the acoustic wave velocity

The propagation velocity of acoustic wave in synthegran is determined by pulse method considering the time difference between signals of vibroacoustic sensors in accordance with the following formula:

$$
C=\frac{S}{\Delta t},
$$

where $\Delta t=t_{1}-t_{2}$ - time difference between signals of vibroacoustic sensors, $\mathrm{s}$;

$t_{1}, t_{2}$ - time of acoustic signals arrival to the first and the second sensors respectively, $\mathrm{s}$.

The difference of damping values, which were found using different methods for the same sample, caused not only by different assumptions of the dissipative forces kind, but the dependence of the accuracy and sensitivity of used experimental methods on the measured value [3]. Such dependence involves an effective domain of the measurement method applicability, in which we can get the most accurate energy dissipation characteristics for a particular material or design element. The proposed measurement method of energy dissipation characteristics in heterogeneous non-metallic materials is indirect with a lot of the measured value changes from tested object to measurement results (Fig. 2), that, as known from [4], leads to the accumulation of measurement errors at each transformation phase.

Now we prepare the budget for indirect measurement uncertainty of damping decrement of synthegran sample. The application of the measurement uncertainty for measurements' quality assessment is described in [5]. This approach includes an assessment of uncertainty:

- uncertainty type $A$ - using methods of mathematical statistics for processing of the measurement results; standards.

- uncertainty type $B$ - using other methods based on using the information from technical

Now we formulate the research task to identify the causes of errors.

We obtain next values by direct measurements: elastic modulus $E=25 \mathrm{GPa}$, Poisson's ratio $v=0,26$, length of sound control base $S=263 \mathrm{~mm}$, time difference between signals of vibroacoustic sensors $\mathrm{t}=132 \mu \mathrm{s}$. We used the samples of regular shape, so the material density was determined by the ratio of its mass to its volume $-\rho=2500 \mathrm{~kg} / \mathrm{m}^{3}$. The next values of damping decrement have been received: $\lambda_{1}=0,027 ; \lambda_{2}=0,028 ; \lambda_{3}=0,027 ; \lambda_{4}=0,027 ; \lambda_{5}=0,027$.

The total uncertainty $u_{C}$ is calculated using the formula:

$$
u_{C}=\sqrt{u_{A}^{2}+u_{B}^{2}} \text {, }
$$

where $u_{A}$ - uncertainty type $A$;

$u_{B}$ - uncertainty type $B$. 


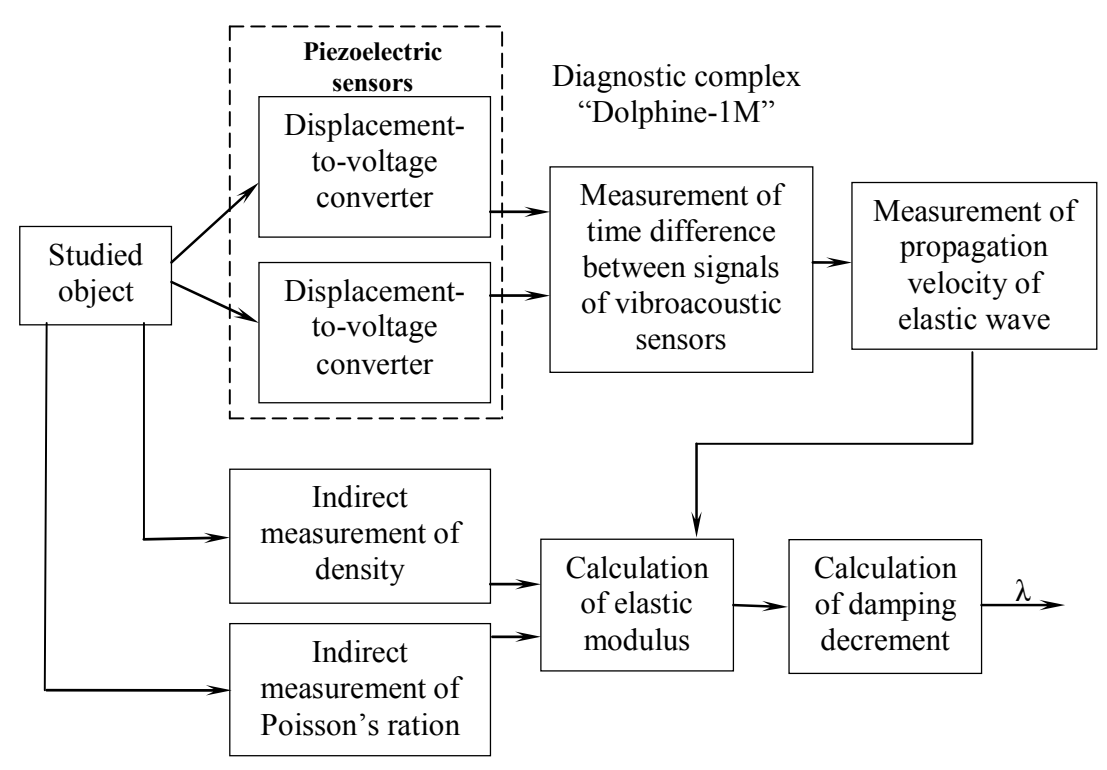

Fig. 2. Block diagram of an acoustic measurement method

The first group of errors (uncertainty type $A$ ) contains of parameters changing of calibrated bump in tolerance limits, displacement of sensor in repeated placement to measurement point, layer thickness variation of contact agent because of irregular hold-down of resolvers to control surface, inaccuracy in reading and etc.

As is well known, the random errors can be evaluated through statistical analysis and can be reduced by averaging over a large number of observations. In practice, to obtain a satisfactory error value at the lowest cost the sufficient repetitiveness is 5 (rarely 7) measurements at the point of control.

The second group of errors (uncertainty type $B$ ) is linked with density and Poisson's ratio measurement errors, distance between sensors, time difference between signals of vibroacoustic sensors.

The standard uncertainty $u_{A}$ of measurement of damping decrement in synthegran (meansquare deviation), when the measurement result is defined as the arithmetic mean, is calculated by the formula:

$$
u_{A}=\sqrt{\frac{1}{n(n-1)} \sum_{i=1}^{n}\left(\lambda_{i}-\bar{\lambda}\right)^{2}},
$$

where $n$ - number of measurements at one point of the controlled surface;

$\lambda_{i}-i$-th vibrations damping decrement value;

$\bar{\lambda}$ - average value of vibrations damping decrement.

By substituting the measurement results, we obtain

$$
\bar{\lambda}=0,0272 ; \quad u_{A}=0,0001 .
$$

Consider the calculation of a standard uncertainty type $B$. Such uncertainty is usually represented as a deviation of values magnitude from its assessment. The most common way to formalize incomplete knowledge of the value is to postulate the uniform distribution of the possible values between the given limits [5]. Thus, for symmetric limits a standard uncertainty is calculated using the formula

$$
u_{B}\left(x_{i}\right)=\frac{b_{i}}{\sqrt{3}},
$$

where $x_{i}$ - assessment of $i$-th input value;

$b_{i}$ - symmetric limits of deviation of the measured value from the measurements. 
The total standard uncertainty type $B$ is calculated using the formula

$$
u_{B}=\sqrt{\sum_{i=1}^{m}\left(\frac{\partial f}{\partial x_{i}}\right)^{2} u_{B}^{2}\left(x_{i}\right)} .
$$

The propagation velocity of elastic waves is determined by the formula (2). There were five measurements, and calculated the arithmetic mean, which amounted to $C=1879 \mathrm{~m} / \mathrm{s}$.

The standard uncertainty $u_{B l}$ of measurement of sound control base length by calipers is

$$
u_{B l}= \pm 0,58 \mathrm{~mm} \text {. }
$$

The relative uncertainty $\delta l$ was calculated using the formula

$$
\delta l=\frac{\Delta l}{l} \cdot 100 \%=0,02 \% .
$$

The phase shift of "Dolphin-1M" complex is less then 1 degree per $\mathrm{Hz}$, and such value can be ignored. Moreover, given that the velocity of elastic waves is determined by the wave-front, and its waveshape does not affect measurement accuracy. Therefore, the uncertainty of time measurement can be determined by quantization error only. Thus, the limits of deviation of the measured value from the measurements can never exceed half of the quantization step size (when rounded to the nearest integer). The time quantization step is $q=3,5 \mu \mathrm{s}$. Therefore,

$$
\Delta q=\frac{q}{2}=\frac{3,5}{2}= \pm 1,75 \mu \mathrm{s} .
$$

According to the formula (8), the standard uncertainty of measurement of time is

$$
u_{B t}= \pm 1,01 \mu \mathrm{s} \text {; }
$$

and in relative form

$$
\delta t=0,77 \% .
$$

Now we find the uncertainty of indirect measurement of density. When the uncertainty of mass measurement is $\pm 0,3 \mathrm{~g}$ and the uncertainty of sample linear dimensions measurement is $\pm 0,6 \mathrm{~mm}$ (by vernier caliper) the relative uncertainty can never exceed $1,2 \%$. So, the standard uncertainty of indirect density measurement will be calculated as follows

$$
u_{B \rho}=\frac{2500 \cdot 1,2}{100}= \pm 29 \mathrm{~kg} / \mathrm{m}^{3} \text {. }
$$

According to the ratings of extensometer "EEO" the relative uncertainty of measurement of Poisson's ration is $0,23 \%$; in absolute terms $-u_{B v}= \pm 0,0006$.

Given (8), the uncertainty of indirect measurement of acoustic wave's velocity in synthegran will be calculated as follows

$$
\begin{gathered}
u_{B w v}=\sqrt{\left(-u_{B t}\right)^{2}+\left(u_{B l}\right)^{2}}, \\
u_{B w v}=14 \mathrm{~m} / \mathrm{s} ;
\end{gathered}
$$

the relative uncertainty of such measurement can never exceed $0,7 \%$.

From (2), we obtain

$$
E=2 \rho C^{2}(1+v) .
$$

According to the formula (8), the standard uncertainty of indirect measurement of elastic modulus will be calculated as follows

$$
u_{B E}=\sqrt{\left(\frac{\partial E}{\partial \rho}\right)^{2} u_{B \rho}{ }^{2}+\left(\frac{\partial E}{\partial v}\right)^{2} u_{B v}{ }^{2}+\left(\frac{\partial E}{\partial C}\right)^{2} u_{B w v}{ }^{2}}
$$


If we take the partial derivatives, we obtain

$$
\Delta E=\sqrt{\left(2 C^{2}[1+v]\right)^{2} u_{B \rho}^{2}+\left(2 C^{2} \rho\right)^{2} u_{B v}{ }^{2}+(4 C \rho[1+v])^{2} u_{B w v}{ }^{2}} .
$$

Finally, the result is

$$
u_{B E}= \pm 132 \cdot 10^{6} \approx \pm 0,1 \mathrm{GPa} .
$$

Using (9), we calculate the relative uncertainty of measurement of elastic modulus

$$
\delta E=\frac{0,1}{25} \cdot 100 \%=0,4 \% .
$$

Now we find the uncertainty of indirect measurement of damping decrement. According to the formula (8), the standard uncertainty of indirect measurement of elastic modulus is calculated as follows:

$$
u_{B \lambda}=\sqrt{\left(\frac{\partial \lambda}{\partial E}\right)^{2} u_{B E}^{2}} .
$$

If we take the partial derivatives, we obtain

$$
u_{B \lambda}=\sqrt{\left(0,0004152 E+2,109 \cdot 10^{-3}\right)^{2} u_{B E}^{2}} .
$$

Substituting values, we obtain

$$
u_{B \lambda}= \pm 0,001 .
$$

In relative form the systematic error of measurement method is

$$
\delta \lambda= \pm 3,7 \% \text {. }
$$

Now we find the total standard uncertainty. Given the standard uncertainty type $A$ is 10 -times less than the standard uncertainty type $B$, and then it can be ignored. So

$$
u_{T}=u_{B \lambda}= \pm 0,001 \text {. }
$$

In practical terms, when calculating the uncertainty of measurement of damping decrement, the distribution of the measured value is accepted as uniform. Such a suggestion is preferred in cases where the uniformity of the values distribution is not proven.

The expanded uncertainty $u_{p}$ for confidence level $P=0,95$ can be represented as

$$
u_{0,95}=k u_{T},
$$

where $k$ - coverage factor, which depends on the confidence level $P$ and the number of degrees of freedom $v_{\text {eff }}$, which is defined by the formula

$$
v_{e f f}=\frac{u_{T}^{4}}{\sum_{i=1}^{m} \frac{u^{4}\left(x_{i}\right)}{v_{i}}\left(\frac{d f}{d x_{i}}\right)^{4}},
$$

where $v_{i}=n_{i}-1$ in the case of uncertainty type $A ; v_{i}=\infty$ in the case of uncertainty type $B$.

Given (17) for the considered case, we obtain

$$
v_{\text {eff }}=\frac{u_{T}^{4}}{\frac{u_{A}^{4}}{n-1}+\frac{\left(\frac{\partial f}{\partial E} u_{B E}\right)^{4}}{\infty}}=4 \cdot 10^{16} .
$$

With this number of degrees of freedom and confidence level $P=0,95$ the coverage factor $k$ is equal to 1,96 [5]. Then, considering (16), the expanded uncertainty is 


$$
u_{0,95}=0,00196 .
$$

So, the final result of measurement of vibrations damping decrement at synthegran can be represented as

$$
\lambda=0,0272 \pm 0,00196,
$$

at $P=0,95$ and uniform distribution law.

Results and Discussion. The method used to study the vibrational energy dissipation characteristics based on coupling of vibrations damping decrement and acoustic velocity in a non-metallic heterogeneous material is reviewed. The international approach for evaluation of measurements quality is used. It includes the common practice international rules for uncertainty expression and their summation. These rules are used as internationally acknowledged confidence measure to the measurement results, which includes testing. Based on analysis of the measurement errors reasons the uncertainties budgeting of acoustic method for measurement of dissipative properties of heterogeneous non-metallic materials were compiled. It was defined that there are two groups of reasons resulting in errors during measurement of heterogeneous non-metallic materials dissipative properties. The first group of errors contains of parameters changing of calibrated bump in tolerance limits, displacement of sensor in repeated placement to measurement point, layer thickness variation of contact agent because of irregular hold-down of resolvers to control surface, inaccuracy in reading and etc. The second group of errors is linked with density and Poisson's ratio measurement errors, distance between sensors, time difference between signals of vibroacoustic sensors. The expanded uncertainty is $u_{0,95}=0,00196$ at confidence level $P=0,95$ and uniform distribution law.

\section{Література}

1. Голофеева, М.А. Акустический метод контроля синтеграновых изделий / М.А. Голофеева // Проблеми техніки. - 2013. - № 3. - С. $119-124$.

2. Prandina, M. An assessment of damping identification methods / M. Prandina, J.E. Mottershead, E. Bonisoli // Journal of Sound and Vibration. - 2009. - Vol. 323, Issues 3-5. - PP. $662-676$.

3. Slaev, V.A. Metrology and theory of measurement / V.A. Slaev, A.G. Chunovkina, L.A. Mironovsky. Berlin; Boston: De Gruyter, 2013. - 560 p.

4. Probability-possibility transformations, triangular fuzzy sets, and probabilistic inequalities / D. Dubois, L. Foulloy, G. Mauris, H. Prade // Reliable Computing. - 2004. - Vol. 10, Issue 4. — PP. 273 - 297.

5. Захаров, И.П. Особенности оценивания неопределенностей результатов параллельных измерений / И.П. Захаров, А.П. Сергиенко, М.П. Сергиенко // Системи обробки інформації. — 2008. Вип. 4(71). - С. $59-62$.

\section{References}

1. Golofeyeva, M.A. (2013). Acoustic control method of synthegran products. Problemy Tekhniky, 3, 119-124.

2. Prandina, M., Mottershead, J.E., \& Bonisoli, E. (2009). An assessment of damping identification methods. Journal of Sound and Vibration, 323(3-5), 662-676. DOI:10.1016/j.jsv.2009.01.022

3. Slaev, V.A., Chunovkina, A.G., \& Mironovsky, L.A. (2013). Metrology and Theory of Measurement. Berlin; Boston: De Gruyter.

4. Dubois, D., Foulloy, L., Mauris, G., \& Prade, H. (2004). Probability-possibility transformations, triangular fuzzy sets, and probabilistic inequalities. Reliable Computing, 10(4), 273-297. DOI: 10.1023/B:REOM.0000032115.22510.b5

5. Zakharov, I.P., Sergienko, A.P., \& Sergienko, M.P. (2008). The particular qualities of analytical measurements uncertainly. Sistemi Obrobki Informacii, 4, 59-62. 